www.volsu.ru

DOI: http://doi.org/10.15688/nav.jvolsu.2017.2.6

UDC 930.26(470+571):903.53

LBC 63.48(2)-427.1

\title{
MATERIALS OF BURIAL MOUND UST-POGOZHYE
}

\author{
Vladislav I. Mamontov \\ Volgograd State Socio-Pedagogical University, Volgograd, Russian Federation \\ Vasiliy V. Mataev \\ Archaeological expedition Ltd., Rostov-on-Don Region, Russian Federation
}

\begin{abstract}
Six burial mounds were excavated near the village of Ust-Pogozhye in the Ilovlinsky District of the Volgograd Region on the Berdiya River (the tributary of the Ilovlya River). There were burials of Yamna culture, Catacomb culture and Srubna culture which belonged to the Bronze Age, the burial of the Sarmatian culture belonged to the $4^{\text {th }}-3^{\text {th }}$ centuries BC. There were also burials of Late Sarmatian culture. A collection of ceramics of Srubna culture is built, among which there are vessels with "magic signs". The Sarmatian burials contained the ceramics of local and imported production, bronze and iron arrowheads, bronze pendants, beads, anthropomorphic figures made from chalk, gypsum druse, etc.
\end{abstract}

Key words: Bronze Age, Yamna culture, Catacomb culture, Srubna culture, Sarmatian culture, burial, kerving, ceramics, arrowheads.

Citation. Mamontov V.I., Mataev V.V., 2017. Materials of Burial Mound Ust-Pogozhye. The Lower Volga Archaeological Bulletin, vol. 16, no. 2, pp. 93-115. (in Russian).

УДК 930.26(470+571):903.53

ББК 63.48(2)-427.1

\section{МАТЕРИАЛЫ КУРГАННОГО МОГИЛЬНИКА УСТЬ-ПОГОЖЬЕ}

\section{Владислав Иванович Мамонтов}

Волгоградский государственный социально-педагогический университет, г. Волгоград, Российская Федерация

\section{Василий Владимирович Матаев}

ООО «Археологическая экспедиция», Ростовская область, Российская Федерация

Аннотация. Раскопаны шесть курганов у пос. Усть-Погожье Иловлинского района Волгоградской области на р. Бердия (приток р. Иловли). В них находились погребения ямной, катакомбной, срубной культур эпохи бронзы, погребения сарматской культуры IV-III вв. до н.э. и позднесарматские погребения. Собрана коллекция керамики срубной культуры, среди которых имеются сосуды с «магическими знаками». В сарматских погребениях отмечена керамика местного и импортного производства, бронзовые и железный наконечники стрел, бронзовые подвески, бусы, антропоморфные фигурки из мела и пластинок друзы гипса и т. д.

Ключевые слова: эпоха бронзы, ямная культура, катакомбная культура, срубная культура, сарматская культура, погребение, подбой, керамика, наконечники стрел.

Цитирование. Мамонтов В. И., Матаев В. В., 2017. Материалы курганного могильника Усть-Погожье // Нижневолжский археологический вестник. Т. 16, № 2. С. 93-115.

В 1986 г. были проведены охранные раскопки курганного могильника, находившегося в 4 км юго-западнее с. Усть-Погожье Дубовского района Волгоградской области. Могильник состоял из 6 насыпей. Находился на краю второй левой террасы, спадающей к пойме р. Бердии (приток р. Иловля). Все находки из курганов хранятся в Волгоградском областном краеведческом музее [Мамонтов, 1986, c. 54-86]. 
V.I. Mamontov, V.V. Mataev. Materials of Burial Mound Ust-Pogozhye

\section{Курган 1}

Диаметр - 20 м, высота - 0,89 м. Погребенную почву в западном направлении от нулевой отметки прорезал ровик, заполненный комковатым суглинком, смешанным с частичками сосновой коры и угольков. Материковый выкид связан с погребением 8.

Находка 1 в насыпи. Кремневый отщеп найден на глубине 0,4 м, на расстоянии 1,5 м к ЮВ от 0. Размер: $5 \times 5,8 \times 1,2$ см (рис. 3,4 ).

Погребение 1. Прямоугольная яма с закругленными углами находилась на расстоянии 2,6 м на ВСВ от нулевой отметки, ориентирована по линии С-Ю. Длина ямы 2,1 м, ширина 0,72 м, глубина 1,35 м. Скелет мужчины (45-50 лет) покоился вытянуто на спине головой на Ю, ближе к западной стенке, руки положены вдоль тела (рис. 1,1).

Сопровождающий инвентарь: кости животного (барана) лежали под левым бедром и между пяточными костями.

Погребение относится к сарматской культуре.

Погребение 2. Овальная яма находилась на расстоянии 2 м на ВЮВ от нулевой отметки, ориентирована по линии С-Ю. Длина ямы $-2,43$ м, ширина - 1,5 м, глубина 1,65 м. Яма ко дну, покрытому тонким слоем мела, сужалась, на уровне дна имела ширину 1,31 м. Скелет мужчины (55-60 лет) лежал на левом боку в скорченном положении, головой на СВ. Кости рук согнуты в локтях, направлены к бедрам (рис. 1,2).

Сопровождающий инвентарь: кости ног крупного рогатого скота (корова?) были положены перед грудной клеткой погребенного.

Погребение относится к эпохе бронзы.

Погребение 3. Кости ребенка находились на глубине 1,3 м. Он положен на левый бок головой на С3. Нижняя часть скелета разрушена ямой впускного погребения (рис. 1,3).

Погребение относится к эпохе бронзы.

Погребение 4. Скелет погребенного (мужчина 55-60 лет) найден на глубине 1,5 м, в юго-западном углу общей ямы, на площадке, сохранившейся у южной и западной сторон. Он покоился на правом боку головой на Ю3, кость предплечья направлена вдоль тела вниз, остальная часть скелета разрушена (рис. 1,4 ).
Погребение относится к эпохе бронзы.

Погребение 5. Овальная яма врезалась в северо-западную часть ямы погребения 6, ориентирована по направлению С3-ЮВ. Длина - 1,62 м, ширина - 1,2 м, глубина - 1,8 м.

Ближе к западной стенке ямы обнаружены кости человека. Видимо, скелет лежал на левом боку в скорченном положении. Судя по позвоночнику, был ориентирован на В. Часть грудной клетки, кости рук, череп - отсутствуют, разрушены грабительской ямой (рис. 1,5).

Погребение относится к эпохе бронзы.

Погребение 6. Прямоугольная яма размерами 2,48 $\times 2,03$ м. Вдоль южной и северной сторон на глубине 0,7 м оставлен заплечик, его ширина у северной стенки $0,47 \mathrm{M}$, у южной $-0,59$ м. Яма шла на глубину 1,46 м. Вдоль южной и северной сторон находились ступеньки шириной 0,23 м у северной стенки и 0,18 м у южной стенки. Дно ямы овальное, ориентировано по линии 3-В. Длина ямы по дну $-1,55$ м, ширина -1 м. Высота ступенек 0,29 м. Общая глубина ямы $-2,25$ м.

Женский скелет (25-30 лет) покоился на правом боку, головой на В, ноги сильно скорчены, руки согнуты в локтях, кисть левой руки лежит между ног, кисть правой - на левом бедре. Под коленями и черепом - слой охры (рис. 1,0).

Погребение относится к ямно-катакомбному времени.

Погребение 7. Яма находилась на расстоянии 3,2 м на Ю от 0 отметки, ориентирована по линии СВ-Ю3. Длина - 2,52 м, ширина 0,68 м. Яма в юго-восточной части уходила до глубины 1,9 м, здесь, вдоль всей стенки, оставлена приступка шириной 0,2 м и высотой 0,2 м. Подбой находился в северо-западной стенке ямы. Длина подбоя - 2,5 м, ширина от среза - 0,5 м. Общая глубина ямы - 2,6 м.

Мужчина (18-20 лет) покоился в подбое на левом боку в слабо скорченном положении, ориентирован головой на $\mathrm{CB}$, левая рука вытянута к бедру, правая - согнута в локте, кисть - на левой (рис. 1,7).

Сопровождающий инвентарь: фрагменты черноглиняного лепного сосуда собраны у тазовых костей. Венчик отсутствует - сломан у основания. Здесь проходят два рельефных валика, сформованные из 
сырой глины тулова путем нажима концом палочки. Пространство между ними заполнено углами, нанесенными штампом «веревочка». Тулово у дна покрыто «елочкой» с помощью мелкозубчатого штампа. На нем видны следы горизонтального сглаживания. Высота сосуда - 15,4 см, диаметр дна $-9,2$ см (рис. 2,4).

Погребение относится к катакомбной культуре.

Погребение 8. С ним связан материковый выкид, отмеченный в бровке. Входная яма овального очертания находилась на Ю3 от нулевой отметки, на расстоянии 2,2 м, ориентирована по линии 3-В. Длина - 2,28 м, ширина - 1,6 м. В засыпи встретились кусочки дерева от перекрытия.

На глубине 1,98 м от 0, у южной стороны ямы, оставлена ступенька шириной 0,7 м, высотой 0,17 м, посыпанная тонким слоем охры. В средней части ступеньки разбросаны кости барана (кости ног, альчики, ребра). В северной стенке ямы вырыт подбой, на его дне отмечен слой охры. Высота подбоя 0,7 м, ширина от основания ступеньки до северной стенки 1,2 м. Подбой ориентирован по линии 3-В, длина - 2,62 м.

В подбое находились два костяка. Скелет мужчины (30-35 лет) лежал на левом боку головой на В, в сильно скорченном положении. Кости его левой руки вытянуты к бедру, кости правой руки, согнутой в локте, лежат на плечевой кости левой руки. Скелет ребенка (до 1 года) находился в западной части подбоя. Он покоился в ногах мужчины на спине, головой обращен на $\mathrm{CB}$, руки вытянуты вдоль тела (рис. 1,8$)$.

\section{Сопровождающий инвентарь:}

1. Тонкостенный баночный сосуд стоял у колен мужчины. Край венчика направлен вовнутрь. Широкая часть тулова, ближе к венчику, оформлена горизонтальными параллельными линиями, прочерченными концом палочки (у венчика 3, ниже 2, еще ниже 2 линии). Причем, в трех местах линии изгибаются под углом. По краю венчика нанесены наклонные короткие нажимы мелкозубчатым штампом, им же нанесены отрезки между линиями и на пространстве у дна, два параллельных ряда этого штампа составляют «елочку». Диаметр устья - 14,2 см, высота - 13,2 см, диаметр дна - 9,6 см. Глина темная, с добавкой мелких частиц битой ракушки. Поверхность тулова имеет следы сглаживания и участки лощения (рис. 3,1 ).

2. Четыре альчика лежали перед левой плечевой костью.

3. Глиняный сосуд баночной формы с уплощенным дном стоял у правого локтя ребенка. Венчик прямой, тулово конусовидное с плечиком, покрыто наклонными линиями сглаживания (как и внутренняя поверхность). Ниже ребра нанесены тройные параллельные круговые линии «веревочки», имеющие три изгиба под углом. Диаметр венчика $-12,1$ см, диаметр дна - 4,5 см, высота сосуда - 11,7 см. Глина темная, с примесью частиц ракушки (рис. 3,2).

Погребение относится к ямно-катакомбному времени.

Погребение 9. Скелет подростка 1316 лет обнаружен в насыпи кургана на глубине 0,41 м, на расстояния 5,7 м в юго-западном направлении от 0. Покоился на левом боку в скорченном положении, головой на В. Кисти согнутых в локтях рук лежали рядом с нижней челюстью.

Погребение относится к срубной культуре.

Погребение 10. Яма квадратная с закругленными углами. Западная часть ямы разрушена впускным погребением 11. Размеры сохранившейся части ямы: $1,7 \times 1,69$ м, глубина - 1,3 м. Дно покрыто слоем охры.

Два скелета покоились на спине, нижняя часть скелетов разрушена. Мужчина (50 лет) лежал головой на В у северной стенки ямы, кости рук направлены к тазовым костям. Женщина (25 лет) положена на спину, южнее мужчины, головой на В, кости рук направлены к тазовым костям. Ноги, стоявшие ранее коленями вверх, завалились на левую сторону. На костях погребенных зафиксированы слабые следы охры (рис. 1,11).

Погребение относится к ямной культуре.

Погребение 11. Яма овального очертания, ориентированная по линии С-Ю, врезалась в западную часть погребения 10. Длина - 1,77 м, ширина - 1,3 м, глубина - 1,47 м от 0 . В северной части ямы на левом боку лежал скелет подростка (10-13 лет), головой на CСВ. Ноги поджаты, руки согнуты в локтях, кисти - перед грудью (рис. 1,10). 
Сопровождающий инвентарь:

1. Фрагментированный лепной толстостенный баночный сосуд поставлен перед лицевыми костями. Глина темная с примесью битой ракушки, дно с защипами. Диаметр устья - 16 см, диаметр дна - 9,2 см, высота сосуда $-16,6$ см (рис. 3,6 ).

2. Фрагменты лепного сосуда встретились у левого предплечья. Глина бледно-коричневая с примесью крошек мела. Венчик направлен вовнутрь, дно с защипами, на тулове видны следы сглаживания от венчика ко дну. Диаметр венчика -12 см, дна -8 см, высота сосуда $-10,5$ см (рис. 3,3 ).

3. Несколько альчиков лежали у восточной стенки ямы.

Погребение относится к срубной культуре.

Полагаем, что основным погребением в кургане 1 было ямное захоронение 10, вокруг ямы которого был выкопан ровик и насыпан небольшой курган. Позднее в его северной поле было устроено захоронение 8 (ямно-катакомбное время). Выкид из этой ямы с подбоем перекрыл ровик, после чего насыпь была досыпана. В курган впущены погребения 6 (ямно-катакомбное), 7 (катакомбная культура), 2-5 (эпоха бронзы), 9 (срубная культура), 1 (сарматская культура).

\section{Курган 2}

Диаметр насыпи - 22 м, высота -0,72 м. Под нулевой отметкой обнаружен слой пережженной земли.

В северном секторе насыпи встречены:

Находка в насыпи 1: фрагменты венчика сероглиняного кувшина сарматской культуры собраны на глубине 0,4 м, на расстоянии 2,1 м к ВСВ от 0. Край венчика (диаметр 14 см) отогнут наружу, горловина широкая. Глина серая с обильной добавкой битой ракушки (рис. 3,5).

Находка в насыпи 2: обломок плоской зернотерки из ракушечника с одной рабочей поверхностью, один край закруглен. Обнаружен рядом с фрагментами венчика сосуда (находка 1). Размеры: $27,4 \times 13,2 \times 2,8$ см (рис. 3,10).

Находка в насыпи 3: череп коровы лежал на глубине 0,48 м, на расстоянии 2,9 м к $\mathrm{CB}$ от нулевой отметки.
Находка в насыпи 4: Череп коровы обнаружен на расстоянии 3,2 м на С3 от нулевой отметки, на глубине 5,7 м.

Находка в насыпи 5: треугольный фрагмент абразива из песчаника с одной рабочей поверхностью лежал рядом с костями коровы (находка 4). Внешний край закруглен. Размеры: $14,4 \times 7,4 \times 7,1$ см (рис. 3,7).

Находка в насыпи 6: фрагмент керамики срубной культуры найден на расстоянии 2,1 м к 3 от нулевой отметки, на глубине 0,8 м. Глина темная с примесью шамота. На черепке видны углы, стороны которых выполнены оттисками крупнозубчатого штампа. Размеры: $6,5 \times 5,4$ см (рис. 3,8).

Погребение 1. Обнаружено в насыпи, на глубине 2 м и на расстоянии 1,1 м к СВ от нулевой отметки. Женщина 22-25 лет покоилась вытянуто на спине, головой на ЮВ. Руки лежали вдоль тела.

Сопровождающий инвентарь: фрагменты сосуда собраны у левой руки. Глина темная с примесью песка, поверхность тулова светло-коричневая. Имеет высокую горловину, диаметром 8,8 см, крутые плечики переходят в широкое тулово, дно уплощено. Высота сосуда 14,4 см (рис. 3,11).

Погребение относится к сарматской культуре.

Погребение 2. Яма каплевидного очертания находилась на расстоянии 5,5 м на ССВ от нулевой отметки, ориентирована по линии СВ-Ю3. Длина $-1,1$ м, ширина - 0,55 м, глубина - 1,3 м. Скелет подростка лежал скорченно на правом боку с завалом на спину, головой на СВ. Руки согнуты в локтях, положены перед грудью (рис. 1,9).

Около ног обнаружены кости ребенка грудного возраста. Покоился на спине головой на В. Около фрагментов черепа - мелкие кусочки охры.

Сопровождающий инвентарь: тонкостенный горшковидный сосуд стоял у головы ребенка. Край венчика, окрашенный пятнами охры, направлен наружу, короткая шейка переходит в тулово, по широкой части которого нанесены три параллельных ряда штампа концентрических кружочков. Такой же ряд нанесен вдоль дна сосуда. Глина черная с добавкой песка. Диаметр венчика - 11,7 см, диаметр дна $-6,8$ см, высота - 10,3 см (рис. 3,12). 
Погребение относится к катакомбной культуре.

Погребение 3. Трапециевидная входная яма обнаружена на расстоянии 3,6 м к Ю от нулевой отметки, ориентирована по линии 3-В. Длина ямы - 2,66 м, ширина - 1,5 м. В засыпи встретились кусочки гнилого дерева от перекрытия. На глубине 1,9 м, вдоль северной стенки, оставлена ступенька шириной 0,61 м и высотой 0,3 м. В восточной части ступеньки отмечены угольки, пепел от костра и прокал земли под ними.

В южной стенке вырыт подбой, ориентированный по линии 3-В. Ширина подбоя от ступеньки до южной стенки - 1,1 м, длина 2,15 м, высота свода - 0,62 м. На слое коричневого органического тлена, в вытянутом положении на спине, головой на 3 , лежал мужчина 50-55 лет. Руки согнуты в локтях, кисти - на лобковых костях (рис. 1,12).

Сопровождающий инвентарь:

1. Фрагменты лепного сосуда найдены в северо-западном углу камеры у основания ступеньки. Край венчика утолщен, прямая горловина переходит в округлое тулово. По этому участку пальцем (?) проведена широкая круговая борозда. Поверхность сосуда светло-коричневая, глина темная, с добавкой битой ракушки. Диаметр венчика $-11,8$ см, высота сосуда - 19,6 см (рис. 3,15).

2. Ребра барана в анатомическом порядке лежали на ступеньке, ближе к западному углу входа. Другая кучка бараньих костей встретилась на дне у основания ступеньки.

3. Фрагменты однолезвийного железного ножа лежали на костях барана, на дне ямы. Черешок с упором, на клинке (сечение каплевидное) видны следы волокон дерева от чехла. Длина сохранившейся части ножа $-9,5$ см, длина черенка - 3 см, ширина $-2,2$ см (рис. 3,14$)$.

4. Мелкие кусочки желтой серы встречены у фрагментов сосуда.

5. Бронзовые трехлопастные наконечники стрел с внутренней втулкой (14 шт.) собраны между пяточными костями. Один наконечник лежал рядом с правым локтем, два наконечника имеют обрезную втулку (рис. 4,1-5).

6. Округлая булава из полированного серого плотного песчаника находилась в юговосточном углу подбоя. Размеры: 7,2 × 8,2 см.
В центре изделия встречными проходами инструмента просверлено округлое сквозное отверстие диаметром 1,7 и 1,9 см (рис. 3,13).

7. Отщеп окаменелого дерева лежал у левой тазовой кости на тонком слое серы. Длина - 6,7 см, ширина - 1,9 см (рис. 3,9).

Погребение относится к сарматскому периоду.

Погребение 4. Яма каплевидного очертания находилась на расстоянии 2,1 м к С3 от нулевой отметки, ориентирована по линии СВ-Ю3. Длина ямы - 1,22 м, ширина - 1,02 м. На глубине 0,42 м, вдоль юго-восточной стенки, проходила ступенька шириной 13 см. Она опускалась под углом ко дну ямы. Высота ступеньки - 0,62 м, общая глубина ямы - 2,04 м. Подбой высотой 0,74 м находился в северозападной стенке. Дно ямы посыпано тонким слоем охры (рис. 1,14).

Скелет ребенка 3-4 лет положен у входа в подбой на правый бок в скорченном положении, головой на СВ. Кости рук направлены к бедрам.

Сопровождающий инвентарь:

1. Глиняный горшковидный сосуд стоял в подбое перед лицевыми костями погребенного. Диаметр венчика - 10,7 cм, диаметр дна $-5,6$ см, высота сосуда $-10,4$ см. Верхний край венчика покрыт «елочкой», выполненной мелкозубчатым штампом. Проходы штампа частично захватывают и верхнюю часть горловины. Короткая горловина переходит в покатое плечико. Широкая часть тулова до дна покрыта «елочкой», исполненной тем же штампом. Дно и участки тулова залощены (рис. 5,1).

2. Кремневый отщеп лежал перед грудью погребенного. Размеры: 2,5 × 1,4 см (рис. 4,6).

Погребение относится к катакомбной культуре.

Погребение 5. Входная яма находилась под нулевой отметкой, имела трапециевидное очертание, углы закруглены. Грабительская воронка, затрагивая северо-западную стенку ямы, шла до глубины 1,6 м. Длина ямы 2,64 м, ширина - 1,82 м, ориентирована по линии СЗ-ЮВ. Северо-западная стенка ямы шла наклонно до глубины 2,27 м, на этом уровне оставлена подтреугольная ступенька шириной 0,75 м, на которой находились разбросанные кости барана. В юго-восточной стене выко- 
пан подбой, дно которого покрыто коричневым тленом, посыпанным слоем охры. Высота свода - 0,61 м, ширина подбоя (от среза свода) $-0,5$ м, длина подбоя - 1,6 м.

Спиной к выходу из подбоя, на левом боку, лежал подросток 12-15 лет, головой на В, ноги поджаты, руки согнуты в локтях, кисть левой - лежала перед тазом, кисть правой на локтевом сгибе левой руки. На костях отмечены следы охры (рис. 1,15).

Сопровождающий инвентарь: кости барана найдены на ступеньке, вторая группа костей лежала у основания ступеньки на дне подбоя.

Погребение относится к катакомбной культуре.

Погребение 6. Прямоугольная яма с закругленными углами разрушена с северной стороны впускным погребением 3. Ориентирована по линии 3-В. Длина ямы - 1,7 м, ширина $-0,95$ м, глубина $-1,4$ м от 0 . Ближе к южной стенке в скорченном положении покоился скелет человека, головой обращен на ЮЮВ. Руки согнуты в локтях, кисти лежали перед лицевыми костями (рис. 1,13).

Сопровождающий инвентарь: изделие из рога овального сечения найдено между локтями и коленями погребенного. Один конец сломан, на нижней части изделия сохранились природные следы крепления рога в черепе животного. В центре просверлено округлое отверстие диаметром 2,3 см, длина 7,8 см (рис. 5,9).

Погребение относится к срубной культуре.

Основным погребением в кургане 2 является захоронение 5 катакомбной культуры, с которым связан материковый выкид. Впускные погребения: 2, 4 - катакомбная культура; 6 - срубная культура; 3 и 1 - сарматская культура. Зольник под нулевой отметкой относится к раннесарматскому захоронению 3.

\section{Курган 3}

Диаметр кургана - 17 м, высота - 0,6 м.

Находка в насыпи 1: Фрагмент керамики лепного сосуда срубной культуры встречен в насыпи на расстоянии 1 м к ССВ от нулевой отметки, на глубине 0,4 м. Глина черная с добавкой песка. У сосуда прямой венчик, украшенный проходами крупнозубчатого штампа. Тем же штампом покрыта верхняя часть тулова и косые нажимы по краю горловины (рис. 4,38).

Погребение 1. Прямоугольная яма с закругленными углами находилась на расстоянии 3,2 м на С3 от нулевой отметки, ориентирована по линии Ю3-СВ. Длина $-2,05$ м, ширина - 1,01 м, глубина - 1,34 м. В засыпи ямы встретились кусочки дерева от перекрытия. Мужчина (30-35 лет) покоился у южной стенки, на спине в вытянутом положении, головой на ЮЗ. Кости правой руки вытянуты к тазовым костям, кости левой, согнутой в локте, лежат кистью рядом с левым плечом (рис. 1,16).

Сопровождающий инвентарь:

1. Лепной глиняный сосудик стоял у правой стопы. Край венчика, отбитый в древности, отогнут наружу, небольшая горловина переходит в широкое тулово. Глина черная с примесью песка, внутренняя и внешняя поверхности сосуда светло-коричневые. Высота сосуда $-9,8$ см, диаметр венчика -4 см, диаметр дна $-6,7$ см (рис. 5,4).

2. Фрагменты железного ножа (сечение каплевидное) лежали между левым коленом и стенкой ямы (рис. 4,40).

3. Кремневый отщеп найден рядом с ножом. Размеры: 4,1 × 1,8 × 1,5 см (рис. 4,8).

Погребение относится к сарматской культуре.

Большое темное пятно зафиксировано в южном направлении от нулевой отметки, на расстоянии 3,1 м. При расчистке выяснилось, что здесь находятся ямы трех погребений $2,5,6$.

Погребение 2. Скелет женщины 50 55 лет обнаружен в засыпи впускной ямы 6 на глубине 1,08 м. Погребенная покоилась на левом боку в скорченном положении, головой на $\mathrm{CB}$, руки согнуты в локтях, кисти направлены к подбородку (рис. 2,2).

Погребение относится к срубной культуре.

При расчистке заполнения общей ямы под нулевой отметкой выяснилось, что здесь устроены ямы для захоронений $3,7,8$, частично разрушенные грабительским перекопом.

Погребение 3. Прямоугольная яма находилась в южной части общей ямы, нарушала южную сторону входа погребения 8, ориентирована по линии 3-В. Яма погребения 3 в 
восточной части разрушена погребением 7. Длина сохранившейся части ямы - 1,58 м, ширина $-0,72$ м, глубина $-0,96$ м.

Разрушенный скелет женщины 20-22 лет лежал головой на 3, на левом боку, с завалом на спину. Руки вытянуты к тазу, кости ног выброшены при сооружении ямы впускного погребения 7 (рис. 1,18).

Погребение относится к эпохе бронзы.

Погребение 4. Кости подростка найдены на расстоянии 1,4 м на ЮЗ от нулевой отметки, на глубине 1,34 м. Скелет лежал на спине головой на 3, кости рук (сохранились до локтевого сгиба) направлены к тазу, кости ног согнуты в коленях, лежат на правой стороне.

Сопровождающий инвентарь: несколько мелких фрагментов от баночного толстостенного сосуда, глина черная в изломе, внешняя поверхность светлая. Диаметр дна с небольшими защипами по краю - 10 см.

Погребение относится к катакомбной культуре.

Погребение 5. Трапециевидная яма примыкала к восточной стенке входной ямы, ориентирована по линии СВ-ЮЗ. Длина - 1,64 м, ширина - 1,37 м, глубина - 1,37 м. На уровне дна яма была прямоугольной с закругленными углами, ее размеры: 1,58 × 0,94 м.

Мужчина 45-50 лет положен на спину, на меловую посыпку, на которой фиксировались крупицы охры, головой на $\mathrm{CB}$, вплотную к северо-западной стене. Ноги, стоявшие ранее коленями вверх, завалились на левую сторону. Правая рука лежала на правой кости таза, левая рука вытянута к левому бедру (рис. 2,3).

Погребение относится к ямной культуре.

Погребение 6. Входная яма находилась на расстоянии 2,8 м на Ю от нулевой отметки, углы закруглены, ориентирована по линии 3-В. Длина ямы - 2,6 м, ширина - 1,52 м. На глубине 1,4 м вдоль южной стороны проходит ступенька шириной 0,77 м. Она наклонно опускается ко дну подбоя, ориентированного по линии 3-В. Подбой овального очертания находился в северной стенке ямы. Длина подбоя 2,8 м, ширина - 1,62 м (от стенки подбоя до основания ступеньки), высота подбоя -0,92 м. Глубина ямы - 2,4 м от 0. Дно подбоя покрыто тленом коричневого цвета и слоем охры. Ближе к основанию свода на спине лежал мужчина 55-60 лет, головой на В. Руки согнуты в локтях и слегка разведены в стороны, кисти у тазовых костей, ноги согнуты в коленях, лежат на левой стороне (рис. 2,1).

Сопровождающий инвентарь: кости барана лежали у основания ступеньки в югозападном углу.

Погребение относится к ямной культуре.

Погребение 7. Прямоугольная яма, впущенная в центр кургана, прорезала восточные стороны погребений 8 и 3 , ориентирована по линии С-Ю. Длина ямы - 2,45 м, ширина 0,81 м, глубина - 2,4 м. Скелет мужчины (5060 лет) разрушен, кости отброшены к южной стенке ямы (рис. 1,19).

Сопровождающий инвентарь: несколько железных трехлопастных черешковых наконечников стрел обнаружены среди костей человека у южной стены ямы (рис. 4,9).

Погребение относится к сарматской культуре.

Погребение 8. Входная яма трапециевидного очертания находилась в центре кургана, ориентирована по линии С-Ю. Восточную сторону прорезала яма погребения 7, южную сторону - яма погребения 3. Длина ямы 1,73 м, ширина $-1,51$ м, глубина $-0,88$ м. На этом уровне вдоль восточной стенки оставлена ступенька шириной 0,74 м и высотой 0,42 м. В западной части ямы находился подбой, вход которого имел прямоугольное очертание, ориентирован по линии С-Ю. Длина ямы - 1,9 м, ширина подбоя (от основания ступеньки до западной стенки подбоя) - 1,27 м, высота свода - 0,45 м. Вход в подбой перекрыт деревянными слегами. Ближе к западной стенке, спиной к ней, покоилась женщина 55-60 лет, лежащая на левом боку в скорченном положении, головой на С. Левая рука вытянута к левому бедру, правая рука, согнутая в локте, лежит на левой плечевой кости (рис. 1,17).

Сопровождающий инвентарь: фрагменты лепного сосуда собраны у правой кисти. Тулово округлое с узким дном, край венчика на высокой горловине отогнут наружу. На противоположных сторонах сосуда у основания горловины имеются утолщенные ручки «ушки». Глина темная, с примесью песка. По краю венчика проходит круговой ряд коротких вдавлений штампом из трех зубчиков. Этим же штампом нанесены два ряда вдавлений по краям ручек и у их основания. В ме- 
сте перехода устья в тулово нанесена «веревочка», от нее вниз и в стороны продавлены углы с несколькими параллельными сторонами. На тулове заметны полосы горизонтального сглаживания. Диаметр устья - 17,4 см, высота -19 см, диаметр дна - 9,8 см (рис. 5,3).

Погребение относится к катакомбной культуре.

Полагаем, что основным погребением в кургане является захоронение 5 (ямная культура). Впускные погребения: 6 - ямная культура; 3, 4, 8 - катакомбная культура; 2 - срубная культура; 7 и 1 - сарматская культура.

\section{Курган 4}

Диаметр кургана - 17 м, высота -0,63 м.

Погребение 1. Подквадратная яма с закругленными углами находилась на расстоянии 4,2 м в северо-западном направлении от нулевой отметки. Длина ямы - 0,86 м, ширина $-0,53$ м, глубина -1 м. В средней части ямы, ближе к восточной стенке, обнаружены разбросанные фрагменты черепа и костей ног ребенка до 1 года.

Сопровождающий инвентарь: фрагменты лепного острореберного сосуда лежали рядом с фрагментами черепа. Диаметр устья - 15 см, диаметр дна с защипами - 7,2 см, высота - 13,2 см. На участке тулова между ребром и краем венчика концом острия прочерчены угол, несколько вертикальных параллельных линий и короткие риски. Глина темная в изломе с примесью песка (рис. 5,2).

Погребение относится к срубной культуре.

Погребение 2. Прямоугольная яма с закругленными углами ориентирована по линии СВ-Ю3. Длина ямы - 1,6 м, ширина 1,3 м. В засыпи встретились мелкие кусочки дерева от перекрытия. На глубине 2,2 м оставлен заплечик высотой 0,11 м. Дно прямоугольное с закругленными углами, его длина 1,03 м, ширина - 0,62 м, общая глубина ямы 2,31 м. Юго-восточная часть срезана ямой погребения 3 (рис. 2,9).

Скелет ребенка (до 1 года) лежал на спине, головой на СВ на слое коричневого тлена. Ноги согнуты в коленях, лежат на правой стороне, руки вытянуты к тазовым костям. На костях заметны слабые пятна охры.
Погребение относится к ямной культуре.

Погребение 3. Прямоугольная яма прорезала юго-восточную сторону ямы погребения 2 , ориентирована по линии С-Ю, углы закруглены. Длина - 2,4 м, ширина - 1,05 м. В засыпи встречены фрагменты тонких коротких плах перекрытия, лежащих поперек ямы. Вдоль восточной стороны на глубине 2,45 м находилась приступка шириной 0,2 м и высотой 0,7 м. Общая глубина ямы $-3,15$ м. Дно выстлано тонкими плахами, посыпанными мелом. Скелет девочки 15-17 лет лежал на спине вытянуто, головой на Ю. Кости рук вытянуты вдоль тела, кисти - под тазовыми костями (рис. 2,10).

Сопровождающий инвентарь:

1. Фрагменты двух бронзовых височных подвесок в полтора оборота найдены под черепом. Изготовлены из тонкой, круглой в сечении, проволоки диаметром 1,5 мм. Диаметр подвески - 1,5 × 1,3 см (рис. 4,10).

2. Небольшая антропоморфная фигурка из мергеля обнаружена на левом локтевом сгибе. Из бруска выточена голова фигурки с резким переходом к шее и плечам. Руки обозначены по сторонам небольшими бугорками. Поверхность со спины стесана ровно, лишь в месте перехода шеи в плечо проточены две наклонные выемки («руки»?). Длина фигурки 7,5 см, ширина у плеч $-3,1$ см (рис. 5,12 ).

3. Низка из 110 стеклянных бус собрана на плечах и шейных позвонках: $a$ - белые бочковидные бусины, ширина - 2 мм, диаметр 3 мм (рис. 4,11); $\sigma$ - бочковидные с внутренней позолотой, ширина - 2 мм, диаметр - 3 мм (рис. 4,12); 8-мелкий цилиндрический белый биcep, ширина -2 мм, диаметр - 2 мм (рис. 4,13).

4. Несколько фрагментов бронзового зеркала собраны ниже правого локтевого сгиба. К центру диск утолщен, края диска острые. Реконструированный диаметр - 8 см (рис. 5,5 ).

5. Фрагменты двух бронзовых колец в полтора оборота из округлой в сечении (диаметр 1,5 мм) проволоки. Диаметр кольца $2,3 \times 1,9$ см (рис. 4,34).

6 . Низка из 59 стеклянных бусин собрана выше тазовых костей. Некоторые аналогичны бусам на шее: $a$ - белые бочковидные (рис. 4,11$) ; 6$ - бочковидные с внутренней позолотой (рис. 4,12); в - бусины с внутренней позолотой с наклонными пазами, диаметр 4 мм, длина - 5 мм (рис. 4,14). 
7. Мелкие фрагменты небольшого глиняного сосуда найдены у правого бедра погребенной. Сосуд не восстановлен, глина темная, с примесью песка. Венчик (диаметр 7 см) прямой.

8. Несколько кусков мела лежали рядом с правой рукой, у берцовой кости и ниже колена.

9. Глиняное биконическое пряслице найдено у левого бедра. Высота - 2,4 см, большой диаметр - 2,6 см, малый диаметр 0,8 см. Острием прочерчены параллельные круговые линии по узкой плоскости пряслица, между ними - косые прочерки. На конической широкой поверхности пряслица видны наклонные насечки, вокруг отверстия прочерчен зигзаг (рис. 4,19).

10. Две антропоморфные подвески из кристаллов друзы гипса найдены среди бусин на поясе погребенной, края сглажены: $a$-пластинка каплевидного очертания размерами $3,6 \times 2,3 \mathrm{~cm}$, в узкой части просверлено отверстие диаметром 1,5 мм (рис. 4,35); $\sigma$ - каплевидная пластинка размерами $3,1 \times 1,6 \mathrm{~cm}$, в узкой части просверлено отверстие диаметром 1,5 мм (рис. 4,18).

11. Фрагменты железного ножа найдены в северо-восточном углу ямы. На черенке следы волокон от деревянной рукояти. Нож имеет горбатую спинку и каплевидное сечение, длина - 7,2 см (рис. 4,37).

12. Кости ноги и лопатка барана лежали в северо-восточном углу ямы рядом с железным ножом.

13. Низка из 48 бусин собрана на стопах погребенной: $a$ - белые цилиндрические бусины из стекла, длина - 5 мм, диаметр $2,5$ мм (рис. 4,15$) ; 6$ - цилиндрические бусины из гешира, длина - 2,5 мм, диаметр - 2 мм (рис. 4,16); в - каплевидная бусина лимонного цвета с белой наклонной полосой, верхний конец расплющен, в нем - овальное отверстие, длина бусины - 1,1 см (рис. 4,7); 2 - бугорчатая бусина из стекла, длина - 3 мм, диаметр 2,5 мм (рис. 4,17). Остальные бусины аналогичны бусам из описанных сборов (рис. 4,11,12,13).

Погребение относится к сарматской культуре.

Погребение 4. Прямоугольная яма с закругленными углами (длина - 2,92 м, ширина $-1,41$ м, глубина $-1,45$ м) ориентирована по линии C-Ю. Северо-западный угол ямы затронут впускным погребением 3. В засыпи встретились фрагменты плах от перекрытия. Ближе к северной стенке, на левом боку лежал скелет мужчины 25-30 лет, черепом ориентированный на ССВ. Ноги слабо скорчены, кости рук, согнутые в локтях, кистями лежали у нижней челюсти (рис. 2,12).

Сопровождающий инвентарь:

1. Фрагменты лепного глиняного сосуда лежали в ногах погребенного. Край венчика утолщен, широкое тулово переходит в узкое дно со слабой закраиной. Глина - темная, с примесью песка. Ниже края венчика, вдоль устья, нанесена волнистая линия в две полосы, выполненная концом острия. На тулове заметны наклонные полосы грубого сглаживания. Диаметр венчика - 20,2 см, диаметр дна $-10,3$ см, высота - 18,4 см (рис. 5,7).

2. Костяная пряжка лежала за спиной погребенного. Поверхность отполирована, кольцо эллипсовидное, с высокой боковой плоскостью. На пряжке вырезано подквадратное ушко со сквозным отверстием. Размеры пряжки $-3,1 \times 3,2 \times 0,8$ см. Размеры сквозного отверстия $-1,9 \times 2,0$ см (рис. 4,21).

3 . Несколько альчиков найдены у северо-восточной стенки ямы.

Погребение относится к срубной культуре.

Погребение 5. Прямоугольная яма с закругленными углами находилась на расстоянии 0,4 м на ВЮВ от нулевой отметки. Ориентирована по линии С-Ю, длина - 1,6 м. Восточная сторона ямы разрушена впускным погребением 8. Грабительская яма разрушала северо-западный угол ямы и частично скелет человека. Ширина оставшейся части ямы - 1 м, глубина $-0,95$ м. Скелет человека лежал ближе к западной стенке на левом боку в скорченном положении, головой на С. Руки согнуты в локтях, положены кистями перед плечами. Череп выброшен при рытье грабительской ямы (рис. 2,6).

Сопровождающий инвентарь: фрагменты сосуда обнаружены перед локтями погребенного. Утолщенная закраина устья сосуда переходит в широкое тулово, дно с защипами по краю. Глина темная с примесью битой ракушки. На тулове заметны следы наклонного сглаживания. Диаметр устья - 16,7 см, диаметр дна $-8,6$ см, высота сосуда - 16 см (рис. 5,13 ).

Погребение относится к срубной культуре. 
Погребение 6. Скелет женщины 40 45 лет (покрыт слоем прутьев) покоился на левом боку, головой на В, в скорченном положении, на расстоянии 5,6 м на Ю3 от нулевой отметки и глубине 1,24 м. Руки согнуты в локтях, кисти - перед нижней челюстью.

Сопровождающий инвентарь: фрагменты глиняного баночного сосуда со следами лощения встретились у лицевых костей. Глина черная с примесью песка. По сырой глине тулова прочерчены острием несколько линий, свастика и ромб. Диаметр устья 12,4 см, диаметр дна - 6,1 см, высота сосуда - 11,2 см (рис. 5,11).

Погребение относится к срубной культуре.

Погребение 7. Прямоугольная яма выделялась на светлой поверхности дна погребения 4 в ее северной части, ориентирована по линии С-Ю, углы закруглены. Длина ямы 1,4 м, ширина - 1,2 м. Яма ко дну сужалась, став округлой в очертании, с размерами $0,89 \times 0,96$ м. Глубина ямы $-2,99$ м. Дно покрыто органической подстилкой коричневого цвета, посыпанной охрой. По середине дна в скорченном положении лежал скелет ребенка 10-12 лет, головой на $\mathrm{CB}$, руки согнуты в локтях, кисти - перед лицевыми костями (рис. 2,11).

Сопровождающий инвентарь:

1. Фрагменты лепного глиняного сосуда лежали между костями рук и восточной стенкой. Короткий венчик прямой, переходящий в плечико, ниже проходит пояс из 4 параллельных рядов ямок, нанесенных концом палочки. Три круговых ряда ямок, исполненных тем же приемом, располагались ближе у дна. Глина темная, с примесью шамота. Диаметр венчика $-15,5$ см, диаметр дна - 10,2 см, высота $-14,6$ см (рис. 5,8 ).

2. Обломки бронзовых подвесок в полтора оборота обнаружены среди фрагментов черепа. Диаметр - 1 см, ширина прута -5 мм, концы расширены (рис. 4,22,23).

3. Кости ноги барана лежали перед лицевыми костями черепа.

Погребение относится к катакомбной культуре.

Погребение 8. Узкая прямоугольная яма, впущенная в насыпь, нарушала восточную стенку ямы погребения 5 , ориентирована по линии С-Ю. Короткие стороны закруглены. Длина ямы $-3,4$ м, ширина $-0,85$ м, глубина -
1,45 м. Восточная сторона ямы разрушала подбой погребения 9. Вплотную к южной стенке, на спине в вытянутом положении, головой на Ю, покоился мужчина 30-35 лет. Правая рука вытянута, кисть - у левой тазовой кости, левая рука согнута в локте, уходя кистью под правую руку (рис. 2,7).

Сопровождающий инвентарь:

1. Небольшой фрагмент железного однолезвийного ножа с изогнутым клинком лежал перед лицевыми костями черепа. Длина сохранившейся части $-6,1 \mathrm{~cm}$, ширина $-1,6 \mathrm{~cm}$ (рис. 5,6).

2. Фрагменты железного кинжала встречены у правой берцовой кости, рукоятью обращен в сторону кисти правой руки. Длина рукояти $-10,5$ см. Перекрестие прямое, не восстанавливается (рис. 5,10).

Погребение относится к сарматской культуре.

Погребение 9. Входная яма, ориентированная по линии С-Ю, имела длину 3,7 м, ширину в узкой части $-0,89$ м, глубину $-1,35$ м. Впускное погребение 8 разрушило подбой и частично скелет погребенного. Подбой находился в западной части ямы. Высота его свода 0,65 м, ширина подбоя $-0,75$ м. На дне встретились мелкие частички охры (рис. 2,8).

Скелет ребенка 10-12 лет лежал на правом боку с завалом на спину, возможно, в скорченном положении, головой на Ю. Руки согнуты в локтях, кисти лежат перед грудью, берцовые кости разбросаны по яме.

Сопровождающий инвентарь: несколько костей барана (лопатка, кости ног) встретились на дне ямы у согнутых рук погребенного.

Погребение относится к катакомбной культуре.

Погребение 10. Прямоугольная яма с закругленными углами, ориентированная по линии СВ-ЮЗ, впущена в яму погребения 11. Длина ямы - 1,95 м, ширина - 0,72 м, глубина - 1,25 м. В засыпи встретились частички дерева от перекрытия. Женщина 30-35 лет покоилась в вытянутом положении на спине, головой на ЮЗ, череп лежал на правой стороне, кости рук положены вдоль тела (рис. 2,13).

Сопровождающий инвентарь:

1. Глиняный кувшин ручной лепки стоял за головой погребенной в юго-западном углу. 
Горловина высокая, край венчика отогнут наружу, тулово реповидное, дно узкое. К венчику и широкой части тулова прикреплена ручка, овальная в сечении. Поверхность тулова светло-коричневая с темными пятнами копоти и лощения. Глина темная, с примесью частиц мела и песка. Диаметр венчика - 11,5 cм, диаметр дна - 7,4 см, высота сосуда - 19 см (рис. 5,14).

2. Фрагменты бронзовых обкладок от деревянного сосуда лежали за черепом погребенной. Бронзовая пластинка изогнута, плотно пригнана к дереву и закреплена двумя штифтами (рис. 4,39).

3. Кости барана лежали рядом с кувшином.

Погребение относится к сарматской культуре.

Погребение 11. Прямоугольная яма с закругленными узкими сторонами, ориентирована по линии СВ-Ю3. Северо-восточная часть ямы разрушена впускным погребением 10. Длина ямы - 3,37 м, ширина - 1,82 м. На глубине 1,35 м от 0 оставлены заплечики. $\mathrm{У}$ северо-восточной стенки ширина заплечика - 0,61 м, у юго-западной $-0,54$ м, у юговосточной $-0,1$ м, у северо-западной $-0,12$ см. В засыпи встречались частички гнилого дерева от перекрытия и кусочки охры. Дно ямы покрыто толстым слоем охры и мела. Скелет женщины 25-30 лет (кости покрыты охрой) лежал на спине, головой на СВ. Правая рука вытянута к бедрам, левая согнута в локте, лежала ниже ребер. Ноги, стоявшие ранее коленями вверх, завалились на правую сторону (рис. 2,14).

Сопровождающий инвентарь: кость ноги барана лежала у северо-западной стенки.

Погребение относится к ямной культуре.

Погребение 12. Яма погребения находилась в районе нулевой отметки, под грабительским перекопом. Он, разрушая северо-восточную часть входной ямы, уходил на глубину 1,04 м от 0 . Входная яма прямоугольного очертания, ориентирована длинной осью по линии С-Ю, углы закруглены, длина ямы 1,68 м, ширина - 1,2 м. Вдоль восточной стенки на глубине 1,24 м располагалась ступенька шириной 0,65 м и высотой 0,44 м. Другая ступенька находилась параллельно первой, ширина ее $-0,57$ м, высота - 0,6 м. Подбой был вырыт в западной стенке, ориентирован по ли- нии С-Ю. Дно покрыто слоем охры. Длина подбоя - 1,8 м, ширина - 0,72 м. Скелет погребенного разрушен (рис. 2,5).

Сопровождающий инвентарь: фрагменты глиняного сосуда встретились в засыпи, они были разбросаны по камере подбоя. Диаметр венчика -14 см, диаметр дна -8 см, высота 11 см. По горловине вкруговую проходят три параллельные линии «веревочки». Глина темная, с примесью мелких частиц ракушки. Форма не восстанавливается (рис. 5,15).

Погребение относится к катакомбной культуре.

Основными захоронениями в кургане, полагаем, были одновременные погребения 11 и 2 , относящиеся к ямной культуре. Остальные - впускные. Погребения 7, 9, 12 отнесены к катакомбной культуре; погребения 1,4 , 5 - к срубной культуре; погребения $3,8,10$ - к сарматскому времени.

\section{Курган 5}

Диаметр кургана - 15 м, высота -0,45 м.

Погребение 1. Овальная яма ориентирована по линии С-Ю, ее длина - 2,64 м, ширина $-1,73$ м. На глубине 2,46 м вдоль западной стенки оставлена ступенька шириной 0,54 м, высотой 0,29 м. Подбой, устроенный в восточной стенке ямы, разрушен. Ширина подбоя - 0,98 м, длина $-2,54$ м, общая глубина $-2,76$ м. Кости скелета женщины (60 лет) сдвинуты к северной стенке.

Сопровождающий инвентарь:

1. Бронзовые подвески из тонкой проволоки (диаметр сечения 0,2 см) обнаружены в северном углу ямы. Диаметр подвески $-1,2$ см (рис. 4,24).

2. Мелкие фрагменты бронзового зеркала найдены среди костей в северной части подбоя.

3. Бусы собраны в засыпи и под костями скелета. Низка состоит из 140 бусин: $a$ - плоские гешировые бусины с небольшим отверстием в центре диаметром 0,6 см (рис. 4,25); 6 - стеклянные бусины белого цвета типа «калачик», диаметр - 0,6 см, ширина - 0,2 см (рис. 4,26); в-стеклянные бусины белого или темно-синего цвета, бочковидные, диаметр 0,5 см, ширина - 0,4 см, (рис. 4,27); - - цилиндрическая коралловая бусина диаметром 
0,4 см, шириной 0,4 см (рис. 4,29); $\partial$ - стеклянные бочковидные бусины, диаметр 0,3 см, ширина - 0,3 см (рис. 4,31); $e$ - цилиндрические стеклянные бусины с внутренней позолотой, длина $-0,5$ см, диаметр $-0,2$ см (рис. 4,30).

4. Фрагмент абразивной плитки из белого плотного песчаника со следами использования. Размеры: $14 \times 6 \times 1,7$ см (рис. 5,17).

Погребение относится к сарматскому периоду.

\section{Курган 6}

Диаметр кургана - 18 м, высота - 0,5 м.

Погребение 1. Яма, ориентированная по линии СВ-Ю3, имела трапециевидные очертания (разрушена грабительским перекопом) с закругленными углами. Длина западной стенки $-2,29$ м, длина восточной стенки $-2,04$ м, ширина ямы - 1,98 м, глубина $-2,07$ м. В засыпи и на дне встретились кости взрослого человека (женщина 40-45 лет). Череп имеет следы деформации.

Сопровождающий инвентарь:

1. Конусовидное глиняноепряслице. Наибольший диаметр - 3,2 см, высота $-2,8$ см (рис. 4,36).

2. Фрагменты бронзовых обкладок деревянного предмета - прямоугольные пластинки согнуты и плотно скреплены с деревянной основой бронзовыми штифтами. Размеры: $1,3 \times 1,2 \times 0,7$ см (рис. 4,20).

3 . Несколько пронизок-спиралей, свернутых из тонкой бронзовой проволоки. Длина 2 см, диаметр - 0,7 см (рис. 4,32).

4. Бусы из стекла (6 шт.): $a$ - цилиндрическая бусина с белым покрытием, длина 0,8 см, диаметр - 0,6 см (рис. 4,28); $\sigma$ - бочковидные бусины светло-голубого цвета, диаметр - 0,7 см, ширина - 0,5 см (рис. 4,33).

5. Фрагменты железных ножниц типа «стригали» лежали в северо-западном углу ямы (рис. 5,16).

6. Кусочек смолы найден в юго-восточном углу ямы.

7. Фрагменты железного шила, длина 8 см. На черенке - следы волокон от деревянной рукояти, острие сломано (рис. 4,41 ).

Погребение относится к позднесарматскому периоду.
Охранные раскопки курганов у поселка Усть-Погожье выявили памятники археологии эпохи бронзы и сарматского периода. Самым ранним населением, которое стало осваивать территории по р. Бердия, были племена ямной культуры. Именно памятники этой поры лежат в основе нескольких курганов могильника: курган 1, погребение 10; курган 3, погребения 5, 6; курган 4, погребения 2,11 (рис. 1,11 , $2,3,1,2,9,14)$.

Погребенные положены в квадратную, трапециевидную или в прямоугольные ямы. Погребение 6 из кургана 3 находилось в подбое. Строго соблюдается обряд положения умершего: тело покоится на спине, ноги, поставленные коленями вверх, позднее завалились на сторону, руки направлены к тазовым костям. На дне, под скелетом, встречена органическая подстилка, посыпанная мелом или охрой. Ориентировка погребенных восточная или северо-восточная. На костях скелетов зафиксированы следы охры. В двух случаях рядом с погребенными встречены кости барана.

Нестандартный обряд отмечен в погребении ямной культуры 6 из кургана 3, где сочетаются ритуальные позиции ямной и катакомбной культур: погребенный лежал в подбое на спине, головой на В, на подстилке из органики. Ноги, стоявшие ранее коленями вверх, завалились налево. Возможно, помещение умершего в подбой (обряд, характерный для катакомбников) - случай тесного контакта пришедших в Волго-Донские степи племен катакомбной культуры, чья духовная и материальная культура оказала, как известно, влияние на некоторые погребальные ритуалы местного ямного населения [Фисенко, 1966, c. 75-76].

Примеры такого воздействия пришлого населения на местные племена были не раз зафиксированы в Волго-Донских степях. Так, в погребениях кургана 3 курганного могильника Цаца (Светлоярский район Волгоградской области. Раскопки В.П. Шилова 1962 г.), бесспорно, проявляются ямные и катакомбные признаки в устройстве погребальных сооружений, положении тел умерших и в сопровождающем инвентаре [Мамонтов, 1966, с. 239].

Волго-Донское междуречье стало тем пространством, где обитали племена донецкой, манычской и среднедонской катакомбных 
культур. Это доказывается появлением синкретических погребений, в которых видны нарушения традиционных обрядов, присущих определенной группе катакомбного населения, что является результатом относительно длительного их сосуществования [Мамонтов, 2000, c. 71].

К раннекатакомбным памятникам (по А.В. Кияшко) можно отнести погребение 8 из кургана 1 (рис. 1,8), где встречены два баночных сосуда: короткошейный с округлым туловом, верхняя часть которого орнаментирована круговыми линиями «елочкой» с помощью мелкозубчатого штампа (рис. 3,1 ) и слабопрофилированный с плечиком-уступом (рис. 3,2 ).

К донецкой группе памятников, полагаем, относится детское погребение 4 из кургана 2 (рис. 1,14), где был поставлен профилированный приземистый сосуд, тулово которого покрыто «елочкой», выполненной мелкозубчатым штампом (рис. 5,1). Подобные сосуды были распространены в южных районах Волго-Донского междуречья. Например, такой горшок встречен в курганном могильнике Первомайский VII на Дону в погребении 4 из кургана 14 (рис. 3,8).

К этому же периоду относятся сосуды короткошейные, с плавной профилировкой и круговым орнаментом, занимающим площадь на широкой части сосуда и у основания дна. Это сосуд из погребения 2 (курган 2), орнаментированный штампом «концентрический кружок» (рис. 3,12$)$ и сосуд из погребения 7 (курган 4), где тулово покрыто наклонными нажимами концом палочки в четыре ряда, тот же прием - три ряда нажимов у дна горшка (рис. 5,8).

В курганах могильника Усть-Погожье были зафиксированы более поздние памятники средней бронзы: погребения средне-донской и манычской культур. Они заметно отличаются не только некоторым изменением в погребальных обрядах, но и своеобразной керамикой, характерной для каждой группы пришедшего сюда населения [Кияшко, 2002, с. 135].

К раструбошейным сосудам, встречаемым в среднедонской культуре [Кияшко, 2002, c. 137 , рис. 112], можно отнести находку из кургана 1. В погребении 7 встречены фрагменты сосуда (рис. 2,4), где отсутствовал сло- манный венчик-раструб. Верхняя часть тулова орнаментирована: горизонтальными круговыми валиками из глины самого тулова, между валиками - круговой ряд углов, исполненных штампом «веревочка». Этот же штамп использован при украшении горизонтального участка тулова у дна сосуда - здесь образовалась «елочка».

К манычской культуре относится погребение в подбое 8 из кургана 3. Умершую сопровождала амфора с небольшими ушкамипетельками по бокам на верхней части тулова, покрытого примитивным орнаментом с использованием «веревочки» (рис. 5,3). А.В. Кияшко считает, что манычскую керамику можно отнести к позднекатакомбному времени [Кияшко, 2002, с. 138 , рис. $119,4,120]$.

Освоение степей Волго-Донского междуречья племенами срубной культуры началось, по мнению Н.М. Малова, с XV в. до н.э. [Малов, 1994, с. 11; Мамонтов, 2000, с. 79]. Окрестности реки Бердии население освоило несколько позднее, показателем чего является отсутствие в раскопанных погребениях ранних типов керамики - острореберных орнаментированных сосудов.

Скелеты погребенных встретились либо в насыпи курганов, либо их тела были положены в прямоугольные ямы на левый бок со скорченными ногами. Руки согнуты в локтях, кисти лежат перед грудью, либо направлены к лицевым костям. Ориентированы головой на $\mathrm{C}, \mathrm{B}, \mathrm{CB}$, ЮB.

Полагаем, что наиболее ранней формой сосудов, среди горшковидной и баночной керамики, собранной в погребениях срубной культуры могильника, является острореберный горшок из детского погребения (курган 4, погребение 1) (рис. 5,2). Сосуд имеет ребро, но это уже не биконический сосуд ранних форм здесь после ребра тулово переходит в широкое прямое устье. По сырой глине сосуда на небольшом участке прочерчены острием угол, вертикальные параллельные линии и риски. Содержание рисунка неясно. То же самое можно сказать и о рисунке на большом баночном сосуде из погребения 4 в кургане 4 (рис. $2,12,5,7)$. Здесь нанесены острием двойные волнистые линии.

В этом же погребении найдена костяная пряжка с заполированной боковой поверхнос- 
тью с небольшим плоским подквадратным выступом, где просверлено круглое отверстие для плотного пришивания к ремню пояса или портупеи (рис. 4,21). Подобные изделия использовались древними как нагрудные застежки портупеи или как поясные пряжки. А в случае похорон их владельца, как считают некоторые исследователи, такими поясами могли связывать руки в локтях и ноги в коленях [Петров, 1983, с. 121].

Баночные сосуды встречены в погребении 11 в кургане 1 (рис. 1,10). Это - высокий горшок, где широкая часть тулова сдвинута кверху (рис. 3,6), второй сосуд - небольшая толстостенная банка, у которой устье сильно направлено вовнутрь (рис. 3,3). Большой горшковидный сосуд вертикальных пропорций с отогнутым наружу краем устья (рис. 5,13 ) находился в погребении 5 из кургана 4 (рис. 2,6). Баночная и горшковидная посуда была широко распространена в хозяйстве срубного населения и стала основным типом керамики вплоть до ухода его с исторической арены.

Интересен для исследователей баночный сосуд из впускного срубного погребения 6 (курган 4) (рис. 5,11), где на широкой части тулова прочерчены острием несколько линий, ромб и свастический знак. Ромбы, квадраты, прямоугольники - символы каких-то понятий, пока не известных нам. Чаще всего исследователи касаются свастики, священного символа древних, обозначающего огонь или солнце [Даркевич, 1960, с. 59]. Возможно, именно с этими символами связан свастический рисунок, встречающийся на разных предметах еще с эпохи мезолита [Формозов, 1953, с. 4].

Можем предположить, что замена стандартного орнамента, встречаемого в массе своей на хозяйственной керамике срубной культуры, на знаки, прочерки, примитивные «рисунки», «резы» связана с зарождением элементов пиктографической письменности [Формозов, 1953, с. 5]. Сосуды с такими «магическими» знаками, понятными узкому кругу людей, могли быть использованы либо во время религиозных общинных действий, либо эти сосуды с доброжелательными, оберегающими знаками предназначались для исполнения какого-то стандартного ритуала в узком семейном кругу (современные: лампадка, кадило и т. д.).
Сосуды с «загадочными знаками» встречены как в погребениях, так и на поселениях срубной культуры Волго-Донских степей. Например, в курганном могильнике Ровное в погребении 4 из кургана 14 [Памятники срубной культуры..., 1993, табл. 13,26], в курганном могильнике Волжский [Мамонтов, 2010, рис. 2,1,2], на Приморской стоянке на Дону [Мамонтов, 1974, с. 101, рис. 4,5], случайные находки сосудов у г. Николаевска Николаевского района, у пос. Колпачки Калачевского района [Хабарова, 1993, рис. 1,2, 3,2, 4,5].

Любопытная находка встречена в погребении срубной культуры 6 в кургане 2 (рис. 1,13). У колен погребенного был положен предмет из кости - обломок обработанного мастером рога животного с природным рельефом на поверхности места крепления рога в черепе животного (рис. 5,9). В центре изделия просверлено округлое (?) отверстие для насаживания на рукоять. Вероятно, это фрагмент навершия костяного жезла, предмета, символизировавшего статус погребенного человека.

Большую группу памятников эпохи раннего железного века курганного могильника в окрестности пос. Усть-Погожье составляют погребения сарматской культуры. Полагаем, что к раннему периоду относятся: погребение 1 из кургана 1 (рис. 1,1 ), погребения 1 (рис. 1,12) и 3 из кургана 2, погребения 1 (рис. 1,16 ) и 7 (рис. 1,19 ) из кургана 3 , погребения 3 (рис. 2,10), 8 (рис. 2,7), 9 (рис. 2,13) из кургана 4. Позднесарматские погребения совершены под индивидуальными насыпями: погребение 1 из кургана 5 и погребение 1 из кургана 6. Эти погребения разрушены грабительскими перекопами.

Наряду с безынвентарными погребениями и погребениями со скромным сопровождающим инвентарем, в курганном могильнике встречены захоронения сарматов с коллекцией предметов, хорошо датирующих само погребение. Это погребение 3 из кургана 2 и погребение 3 из кургана 4 (рис. 2,10).

Погребение 3 из кургана 2 (рис. 1,12). Ссылаясь на мнение М.Г. Мошковой [Мошкова, 1963, табл. 14,15,16], И.В. Сергацков датирует его второй половиной IV - III в. до н.э. [Сергацков, 1992, с. 164] по найденным наконечникам стрел - трехлопастным брон- 
зовым наконечникам с внутренней втулкой (рис. 4,1,2,4) и наконечникам с выступающей обрезной втулкой (рис. 4,3,5). К ранним формам сарматской керамики относится толстостенный лепной шаровидный сосуд (рис. 3,15). М.Г. Машкова относит подобные типы сосудов к IV в. до н.э. [Мошкова, 1963, табл. 9,20, 10,19].

Уникальной находкой в этом сарматском погребении, на наш взгляд, является круглая грубо отполированная булава из плотного серого песчаника (рис. 3,13). Вряд ли этот предмет являлся своеобразным символом власти, как это могло быть в эпоху бронзы у представителей властных структур. По всей видимости, это было ударное оружие ближнего боя, типа «кистень». В отверстие изделия продевалась кожаная лента, которую крепко держал в руке воин - так он мог нанести в ближнем бою сильный удар по противнику.

Погребение 3 из кургана 4 (рис. 2,10) захоронение девушки, где в коллекции сопровождающих вещей найдены предметы, хорошо датирующие погребение, прежде всего, это бусы, которые были собраны на плечах, поясе и на стопах погребенной. Бочковидные бусы из стекла белого цвета (рис. 4,11), тип 17 по Е.М. Алексеевой [Алексеева, 1978, с. 65, табл. 33,1] и бочковидные бусы с внутренним золочением (рис. 4,12), которые относятся ею к типу 1 [Алексеева, 1978, с. 29, табл. 26,2]. Эта группа бус датируется I-II вв. н.э. Амфоровидная бусина сине-желтого стекла (рис. 4,7) относится к типу 198 [Алексеева, 1978 , с. 44 , табл. 27,78$]$ и датируется так же, как и стеклянная бугорчатая бусина (рис. 4,17 ) началом эры. Цилиндрические стеклянные бусины (рис. 4,15) относятся к типу 55 [Алексеева, 1978, с. 67, табл. 33,11], датируются IIII вв. н.э. Цилиндрические гешировые мелкие бусины из погребения (рис. 4,16) часто встречаются в сарматских погребениях в течение всего периода обитания этих племен в Волго-Донских степях.

Среди бус на поясе были встречены две уникальные подвески из тонких пластин друзы гипса. Их можно трактовать как примитивные антропоморфные фигурки (рис. 4,18,35), возможно, выполнявшие роль оберега. Интересна также находка антропоморфной фигурки, выточенной мастером из прямоугольного кус- ка мела. Такие изделия, с различной точностью передающие детали тела человека, известны из погребений раннесарматской культуры. А.С. Скрипкин предположил, что подобные фигурки встречаются в женских погребениях, что они несут какую-то определенную религиозную нагрузку «анимистического характера» [Скрипкин, 1991, с. 127, рис. 1,4-9, $132-133$, с. 130 , рис. 2,1-6]. Полагаем, что такие фигурки связаны с определенной ролью женщины в сарматской семье.

Вызывает интерес кувшин из впускного сарматского погребения 10 из кургана 4 (рис. 5,14). Такой формы кувшины с резко отогнутым венчиком и ручкой, приподнятой над краем горловины, часто встречаются на Кубани как в кружальном, так и в лепном исполнении [Марченко, 1996, рис. 27,30-33,35,37, $31,71,72,32,84]$. На Дону и Волге аналогии кувшину нам неизвестны.

Заключают группу памятников сарматской культуры в курганном могильнике УстьПогожье позднесарматские погребения из курганов 5 и 6, разрушенные грабительскими перекопами. Погребение 1 из кургана 5 устроено в подбое. Здесь были найдены бронзовые спиральные подвески, мелкие фрагменты бронзового зеркала, абразивная плитка, бусы из стекла, гешира, коралла. Гешировые бусины круглые, тонкие, с небольшим отверстием в центре (рис. 4,25). Они относятся к типу 27 а и, по мнению Е.М. Алексеевой, бытовали в эллинистическое и римское время [Алексеева, 1978, с. 14, табл. 20,41]. Крупные бусы белого цвета («калачик») из стекла относятся к типу 17 (рис. 4,26), встречаются в сарматских погребениях начиная с I-II вв. н.э., известны они и в более позднее время [Алексеева, 1978, с. 65, табл. 33,1]. Встречены цилиндрические коралловые бусины, которые были известны древним народам уже с IV в. до н.э. и продолжали существовать до IV в. н.э. [Алексеева, 1982, с. 27, табл. 43,27,29,30,48].

Погребение 1 из кургана 6 имело прямоугольную яму, разрушенную грабительским перекопом, кости женского скелета были разбросаны по камере. Здесь также есть предметы, которые дают датировку памятника. Среди набора бус встречены спиралевидные пронизки из бронзы (рис. 4,32), которые относятся к типу 31 и датируются I-II вв. н.э. 
[Алексеева, 1982, с. 28, табл. 42,11]. Кроме того, в погребении найдены фрагменты железных ножниц (рис. 5,16). Они часто встречаются в могильном инвентаре сарматов позднего времени [Сергацков, 2000, рис. 4,3, 17,62, 74,5; Скрипкин, 1984, с. 149, рис. 15,20-23].

А.П. Медведев считает, что миграция сарматов в воронежскую лесостепь началась в III-II вв. до н.э. [Медведев, 1992, с. 30]. Их движение, судя по материалам погребений, проходило с запада (Северное Причерномо- рье), юга (Кавказ) и юго-востока (Средняя Азия) [Медведев, 1992, с. 24]. Самое раннее сарматское погребение в могильнике УстьПогожье относится к IV-III вв. до н.э. (курган 2, погребение 3), сопровождающий инвентарь которого, как считал И.В. Сергацков, связан с передвижением «приуральских кочевников-сарматов» [Сергацков, 1992, с. 172]. Позднее в этот район продвинулись сарматы и из районов северной части Волго-Донского междуречья. 


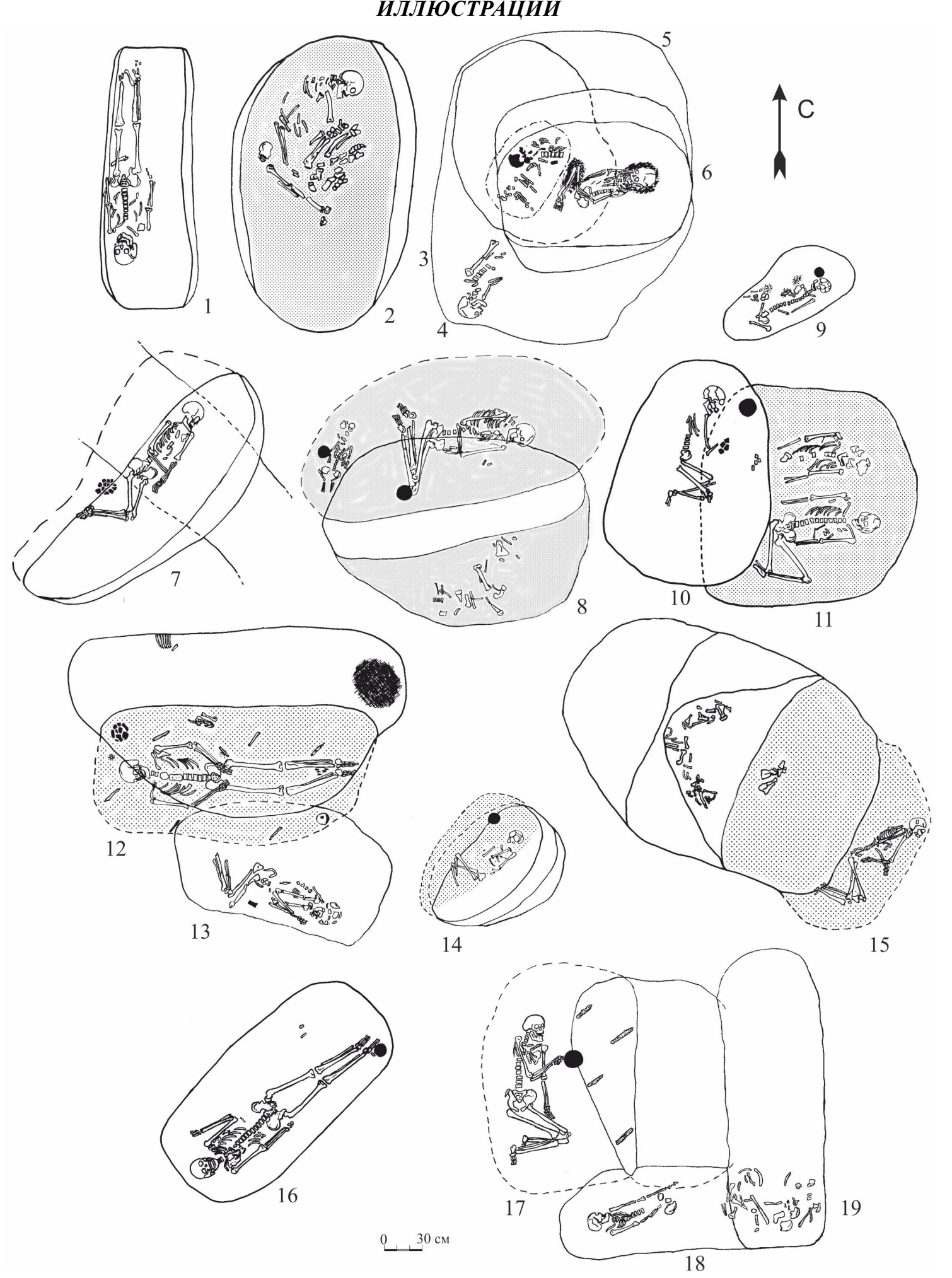

Рис. 1. Планы погребений курганного могильника Усть-Погожье:

Кург. $1: 1$ - погр. 1; 2 - погр. 2; 3 - погр. 3; 4 - погр. 4; 5 - погр. 5; 6- погр. 6; 7 - погр. 7; 8- погр. 8; 10 - погр. 11; 11 - погр. 10. Кург. 2: 9 - погр. 2; 12 - погр. 3; 13 - погр. 6; 14 - погр. 4; 15 - погр. 5. Кург. 3: 16 - погр. 1; 17 - погр. $8 ; 18$ - погр. $3 ; 19$ - погр. 7

Fig. 1. Plans of burials of the burial mound near the village of Ust-Pogozhye:

Burial mound $1: 1$ - burial $1 ; 2$ - burial $2 ; 3$ - burial $3 ; 4$ - burial $4 ; 5$ - burial $5 ; 6$ - burial $6 ; 7$ - burial 7;8- burial 8; 10 - burial 11;11 - burial 10. Burial mound 2:9-burial 2;12 - burial 3;13 - burial $6 ; 14$ - burial 4; 15 - burial 5. Burial mound 3: 16 - burial 1;17- burial $8 ; 18$ - burial 3;19- burial 7 
V.I. Mamontov, V.V. Mataev. Materials of Burial Mound Ust-Pogozhye
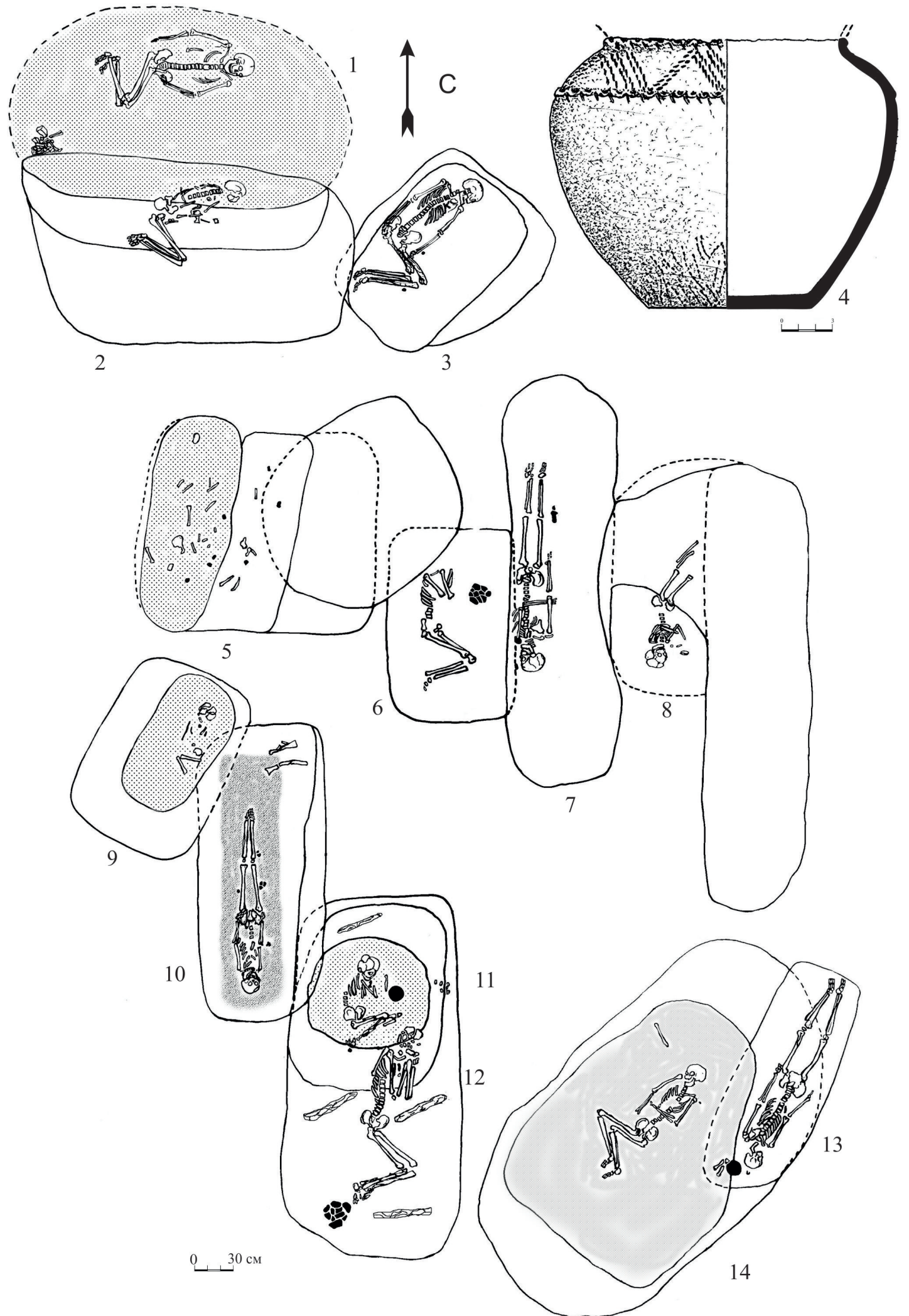

Рис. 2. Планы погребений и инвентарь курганного могильника Усть-Погожье:

4 - кург. 1, погр. 7. Кург. 3: 1 - погр. 6; 2 - погр. 2; 3 - погр. 5. Кург. 4: 5 - погр. 12; 6 - погр. 5; 7 - погр. 8; 8 погр. 9; 9 - погр. 2; 10 - погр. 3; 11 - погр. 7; 12 - погр. 4; 13 - погр. 10; 14 - погр. 11

Fig. 2. Plans of burials and inventory of the burial mound near the village Ust-Pogozhye:

4 - burial mound 1, burial 7. Burial mound 3: 1 - burial $6 ; 2$ - burial 2; 3 - burial 5. Burial mound 4: 5 - burial 12; 6 - burial $5 ; 7$ - burial $8 ; 8$ - burial $9 ; 9$ - burial $2 ; 10$ - burial $3 ; 11$ - burial $7 ; 12$ - burial $4 ; 13$ - burial 10;14- burial 11 

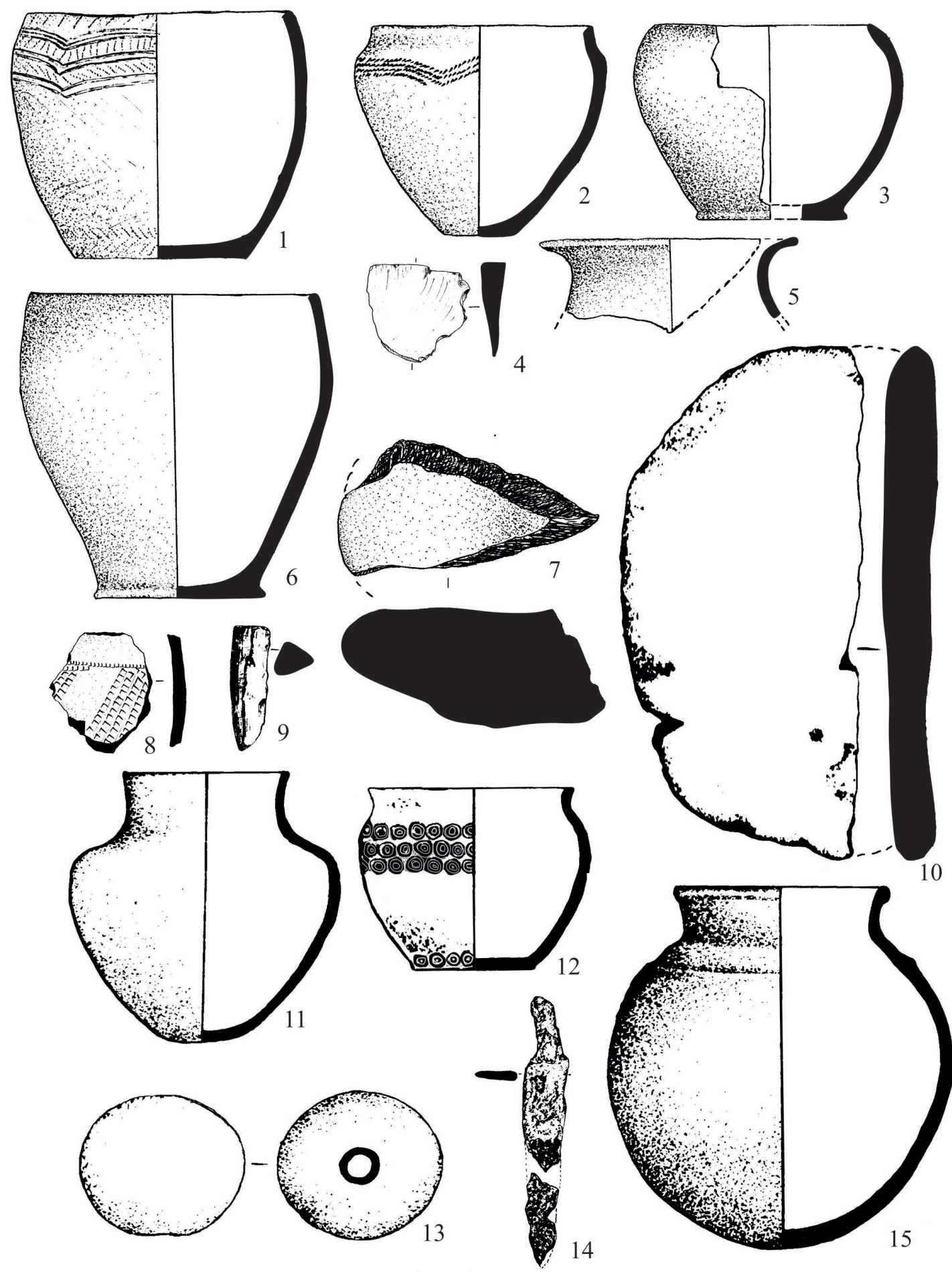

14

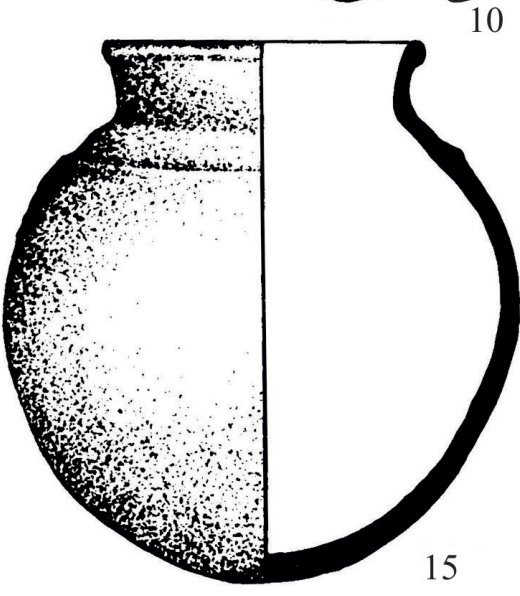

Рис. 3. Инвентарь из погребений курганного могильника Усть-Погожье:

Кург. 1: 1, 2 - сосуды из погр. 8; 3, 6- сосуды из погр. 11; 4 - находка 1 в насыпи (кремневый отщеп). Кург. 2: 5 находка 1 в насыпи (фрагмент венчика сосуда); 7 - находка 5 в насыпи (фрагмент абразивного камня); 8 - находка 6 в насыпи (фрагмент керамики); 10 - находка 2 в насыпи (фрагмент зернотерки); погр. 3: 9 - обломок окаменелого дерева; 13 - каменная булава; 14 - фрагмент железного ножа; 15 - сосуд; 11 - сосуд из погр. $1 ; 12$ - сосуд из погр. 2

Fig. 3. Inventory from the burials of the burial mound near the village Ust-Pogozhye:

Burial mound 1:1, 2 - vessels from burial 8;3,6-vessels from burial 11;4- find 1 in the mound (flint flake).

Burial mound 2:5 - find 1 in the mound (fragment of the corolla of the vessel); 7 - find 5 in the mound

(fragment of abrasive stone); 8 - find 6 in the mound (fragment of ceramics); 10 - find 2 in the mound

(fragment of the grain box); Burial 3:9- fragment of the petrified tree; 13 - stone mace; 14 - fragment of an iron knife; 15 - vessel; 11 - vessel from burial 1; 12 - vessel from burial 2 


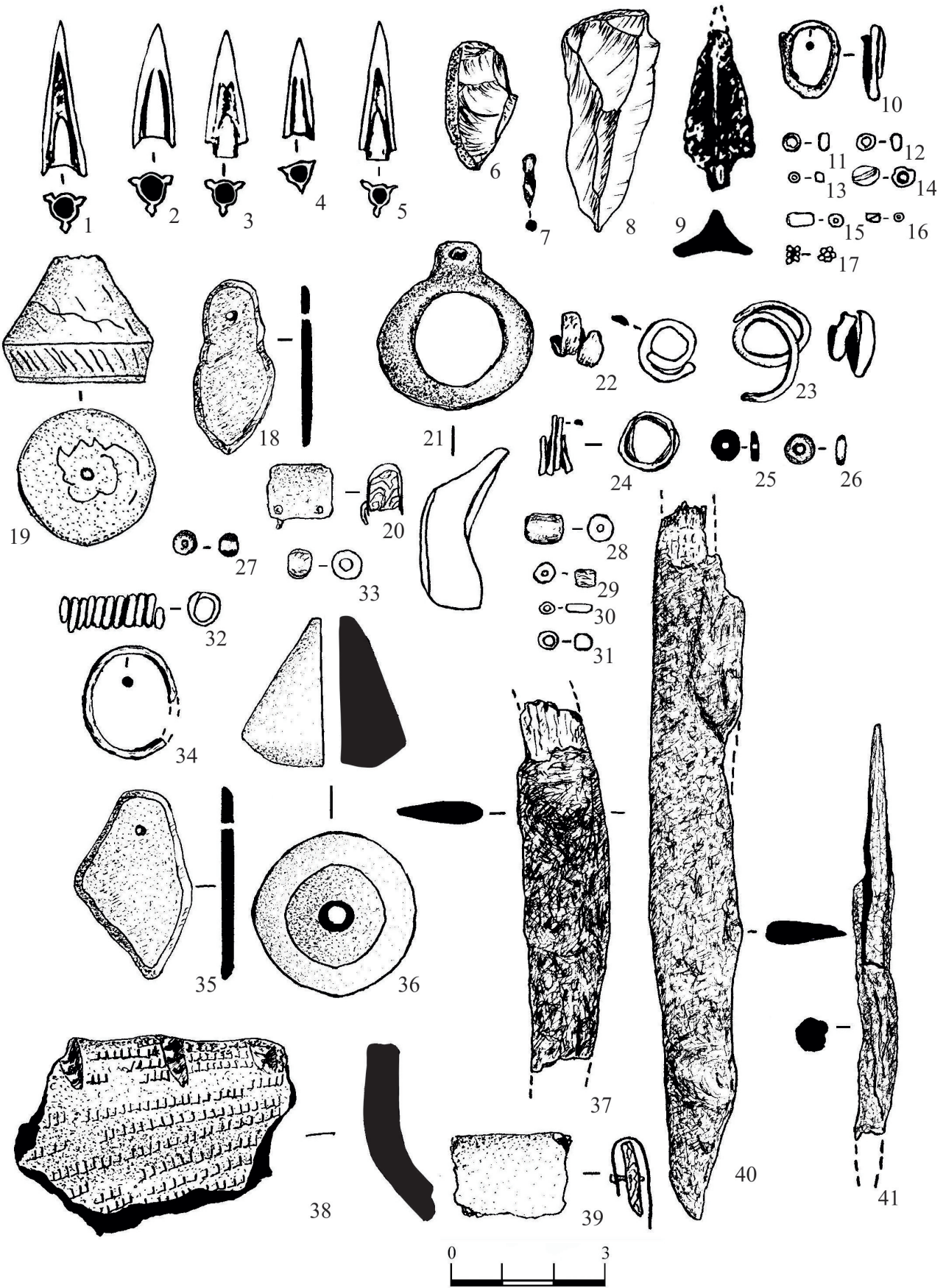

Рис. 4. Инвентарь из погребений курганного могильника Усть-Погожье:

Кург. 2: 1-5 - бронзовые наконечники стрел из погр. 3; 6- отщеп кремня из погр. 4. Кург. 3: 9 - железный наконечник стрелы из погр. 7; 38 - находка 1 в насыпи (фрагмент керамики); погр. 1:8 - отщеп кремня; 40 - фрагмент железного ножа. Кург. 4: 21 - костяная пряжка из погр. $4 ; 39$ - бронзовая обойма из погр. 10; 22, 23 - бронзовые подвески из погр. 7; Погр. 3: 7, 11-17 - бусы; 10 - бронзовая подвеска; 18, 35 - подвески из кристаллов гипса; 19 - глиняное пряслице; 34 - бронзовое кольцо; 37 - фрагмент железного ножа. Кург. 5, погр. 1: 24 - бронзовая подвеска; 25-27,

29-31 - бусы. Кург. 6, погр. 1: 20 - бронзовая обойма; 28, 33 - бусы; 32 - бронзовая подвеска; 36 - глиняное пряслице; 41 - фрагмент железного шила

Fig. 4. Inventory from the burials of the burial mound near the village Ust-Pogozhye:

Burial mound 2: 1-5 - bronze arrowheads from burial 3; 6 - flint flake from burial 4.

Burial mound 3: 9 - iron arrowhead from burial 7; 38 - find 1 in the mound (fragment of ceramics); Burial 1: 8 - flint flake; 40 - fragment of an iron knife. Burial mound 4:21 - bone buckle from burial 4; 39 - a bronze holder from burial 10;

22, 23 - bronze pendants from burial 7; Burial 3: 7, 11-17 - beads; 10 - bronze pendant; 18,

35 - pendants from gypsum crystals; 19 - clay spindle; 34 - bronze ring; 37 - fragment of an iron knife.

Burial mound 5, burial 1: 24 - bronze pendant; 25-27, 29-31-beads. Burial mound 6, burial 1:20 - bronze holder; 28,33 - beads; 32 - bronze pendant; 36 - clay spindle; 41 - fragment of an iron awl 


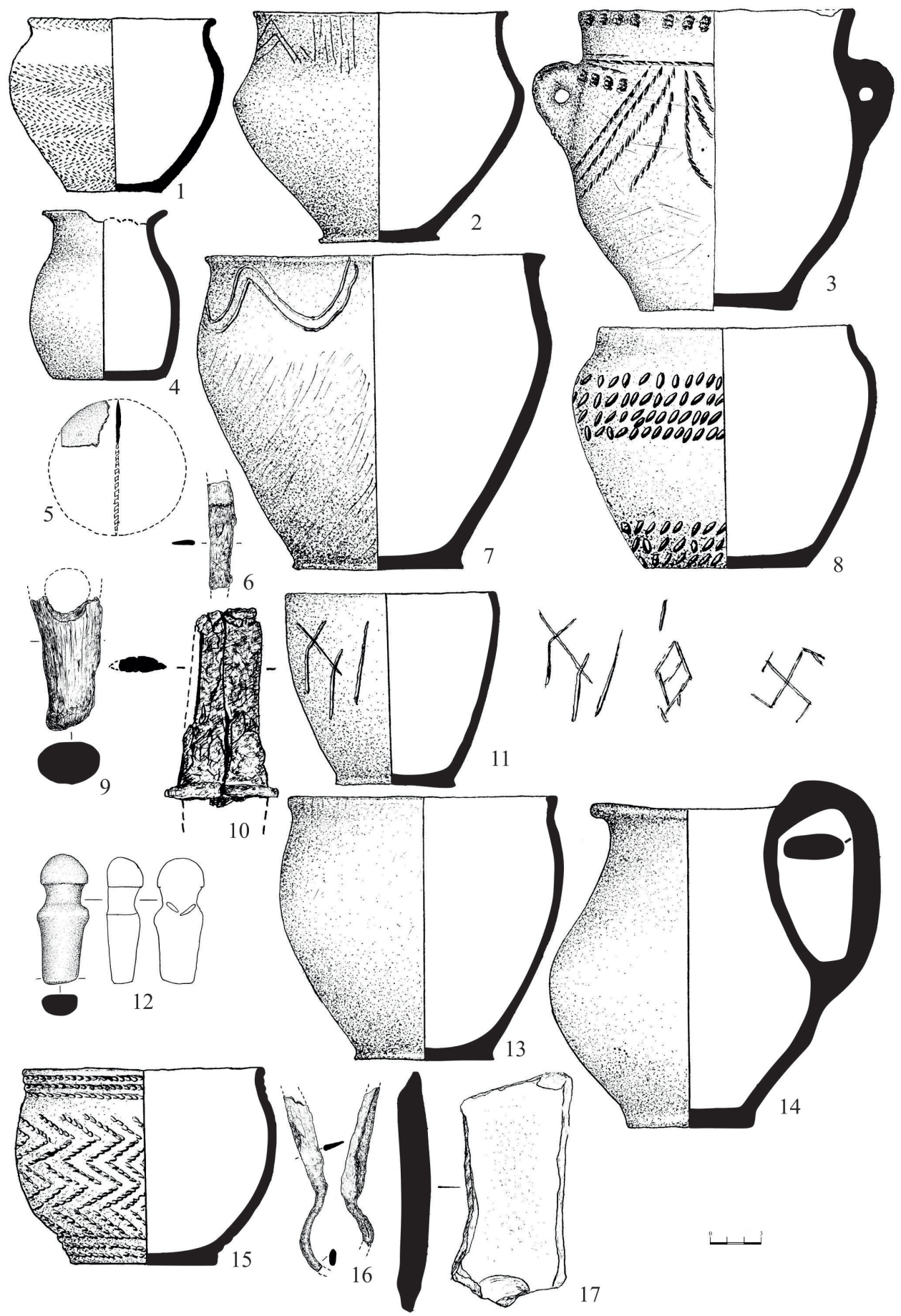

Рис. 5. Инвентарь из погребений курганного могильника Усть-Погожье:

Глиняные сосуды: 1 - кург. 2, погр. 4; Кург. 3: 3 - погр. 8; 4 - погр. 1; Кург. 4: 2 - погр. 1; 7 - погр. 4; 8 - погр. 7; 11 - погр. 6; 13 - погр. 5; 14 - погр. 10; 15 - погр. 12. Кург. 4, погр. 3: 5 - фрагмент бронзового зеркала; 12 - антропоморфная фигурка; погр. 8: 6 - фрагмент железного ножа; 10 - фрагмент железного кинжала; 9 - орудие из рога из погр. 6 кург. 2; 16 - фрагмент железных ножниц из погр. 1 кург. 6 ; 17 - фрагмент абразивной пластинки из погр. 1 кург. 5

Fig. 5. Inventory from the burials of the burial mound near the village Ust-Pogozhye: Clay vessels: 1 - burial mound 2, burial 4; Burial mound 3:3- burial 8;4- burial 1; Burial mound 4:2-burial 1; 7 - burial $4 ; 8$ - burial 7;11 - burial $6 ; 13$ - burial $5 ; 14$ - burial 10;15 - burial 12. Burial mound 4, burial 3: 5 - fragment of the bronze mirror; 12 - anthropomorphic figure; Burial 8: 6 - fragment of an iron knife; 10 - fragment of an iron dagger; 9 - gun from the horn from burial 6 of burial mound 2; 16 - fragment of iron scissors from burial 1 of burial mound 6; 17 - fragment of an abrasive plate from burial 1 of burial mound 5 


\section{СПИСОК ЛИТЕРАТУРЫ}

Алексеева Е. М., 1978. Античные бусы Северного Причерноморья. М. : Наука. 120 с.

Алексеева Е. М., 1982. Античные бусы Северного Причерноморья. М. : Наука. 105 с.

Даркевич В. П., 1960. Символы небесных светил в орнаменте древней Руси // Советская археология. № 4. С. 56-67.

Кияшко А. В., 2002. Культурогенез на востоке катакомбного мира. Волгоград : Изд-во ВолГУ. $266 \mathrm{c}$.

Малов Н. М., 1994. Культурные типы памятников срубной культурно-исторической области // Срубная культурно-историческая область. Саратов : Изд-во Сарат. ун-та. С. 8-13.

Мамонтов В. И., 1966. Курган эпохи бронзы у с. Цацы близ Волгограда // Советская археология. № 1. С. 236-239.

Мамонтов В. И., 1974. Приморская стоянка // Историко-краеведческие записки. Вып. ІІ. Волгоград : Ниж.-Волж. кн. изд-во. С. 94-103.

Мамонтов В. И., 1986. Отчет о работе Приволжского отряда ЛОИА АН СССР и Донской экспедиции ВГПИ за 1986 г. // Архив ВОКМ. № 50.

Мамонтов В. И., 2000. Древнее население левобережья Дона (по материалам курганного могильника Первомайский VII). Волгоград : Изд-во ВолГУ. 190 с.

Мамонтов В. И., 2010. Курганные могильники у г. Волжского // Нижневолжский археологический вестник. Вып. 11. С. 306-321.

Марченко И. И., 1996. Сираки Кубани (по материалам курганных погребений Нижней Кубани). Краснодар : Изд-во Кубан. гос. ун-та. 339 с.

Медведев А. П., 1992. К вопросу о времени появления сарматов в лесостепном Подонье // Проблемы хронологии сарматской культуры. Саратов : Изд-во Сарат. ун-та. С. 24-31.

Мошкова М. Г., 1963. Памятники прохоровской культуры // Свод археологических источников. Вып. Д1-10. М. : Изд-во АН СССР. 54 с.

Памятники срубной культуры Волго-Уральского междуречья, 1993 // Археология России. Сборник археологических источников. Вып. 1-10. Саратов : Изд-во Сарат. ун-та. 200 с.

Петров Ю. Э., 1983. Костяные пряжки раннесрубного времени на территории Среднего Поволжья // Культуры бронзового века Восточной Европы : межвуз. сб. науч. тр. Куйбышев : Изд-во Куйбышев. пед. ин-та. С. 118-122.

Сергацков И. В., 1992. О времени заселения сарматами северной части Волго-Донского междуречья // Советская археология. № 1. С. 162-174.

Сергацков И. В., 2000. Сарматские курганы на Иловле. Волгоград : Изд-во ВолГУ. 395 с.
Скрипкин А. С., 1984. Нижнее Поволжье в первые века нашей эры. Саратов : Изд-во Сарат. ун-та. $150 \mathrm{c}$.

Скрипкин А. С., 1991. Антропоморфные статуэтки в погребальном обряде сарматов // Археология Восточно-Европейской степи. Вып. 2. Саратов : Изд-во Сарат. ун-та. С. 126-134.

Фисенко В. А., 1966. Погребальный обряд племен катакомбной культуры юго-востока // Археологический сборник. Саратов : Изд-во Сарат. ун-та. С. 63-83.

Формозов А. А., 1953. Сосуды срубной культуры с загадочными знаками // Вестник древней истории. № 1. С. 1-8.

Хабарова Н. В., 1993. Случайные находки эпохи бронзы из фондов Волгоградского областного краеведческого музея // Древности ВолгоДонских степей : сб. науч. ст. Вып. 3. Волгоград: Перемена. С. 240-247.

\section{REFERENCES}

Alekseyeva E.M., 1978. Ancient beads of the North Pontic Region. Moscow, Nauka Publ. 120 p. (in Russian).

Alekseyeva E.M., 1982. Ancient beads of the North Pontic Region. Moscow, Nauka Publ. 105 p. (in Russian).

Darkevich V.P., 1960. Symbols of heavenly bodies in the ornament of ancient Russia. Sovetskaja arkheologiya, no. 4, pp. 56-67. (in Russian).

Kiyashko A.V., 2002. Cultural genesis in the east of the catacomb world. Volgograd, Izd-voVolGU. 266 p. (in Russian).

Malov N.M., 1994. Cultural types of monuments in the cultural-historical field of Srubna culture. Srubnaia kulturno-istoricheskaia oblast'. Saratov, Izd-vo Sarat. un-ta, pp. 8-13. (in Russian).

Mamontov V.I., 1966. Mound of the Bronze Age near the village Tsatsa near Volgograd. Sovetskaja arkheologiya, no. 1, pp. 236-239. (in Russian).

Mamontov V.I., 1974. Maritime type-site. Istorikokraevedcheskie zapiski, iss. II. Volgograd, Nizhnevolzh. kn. izd-vo, pp. 94-103. (in Russian).

Mamontov V.I., 1986. The report on work of the Volga group of LOIA Academy of Sciences and the Don expedition VSPI for 1989. Arkhiv VOKM, no. 63. (in Russian).

Mamontov V.I., 2000. The ancient population of the left bank of the Don (based on the materials of the burial cemetery Pervomaiskii VII). Volgograd, Izd-vo VolGU. 190 p. (in Russian).

Mamontov V.I., 2010. Burial mounds near the city Volzhsky. The Lower Volga Archaeological Bulletin, iss. 11, pp. 306-321. (in Russian). 
Marchenko I.I., 1996. Siraki of the Kuban (based on the burial mounds of the Lower Kuban'). Krasnodar, Izd-vo Kubanskogo gos. un-ta. 339 p. (in Russian).

Medvedev A.P., 1992. On the time of the Emergence of the Sarmatians in the Forest-steppe Don region. Problemy khronologii sarmatskoi kultury.. Saratov, Izd-vo Sarat. un-ta, pp. 24-31. (in Russian).

Moshkova M.G., 1963. Monuments of Prokhorov culture, iss. D1-10. Moscow, Izd-vo AN SSSR. 54 p. (in Russian).

Monuments of Srubna culture of the Volga-Ural interfluve, 1993. Arkheologiia Rossii. Svod arkheologicheskikh istochnikov, iss. 1-10. Saratov, Izd-vo Sarat. un-ta. 200 p. (in Russian).

Petrov Yu.E., 1983. Bones buckles of early time of the Srubna culture in the Middle Volga region. Kultury bronzovogo veka Vostochnoi Evropy. Kuibyshev, Izd-vo Kuibysh. ped. ins-ta, pp. 118122. (in Russian).

Sergatskov I.V., 1992. About the time of settling the Sarmatians of the northern part of the VolgaDon interfluve. Sovetskaja arkheologiya, no. 1, pp. 162-174. (in Russian).
Sergatskov I.V., 2000. Sarmatian burial mounds in the Ilovlya river. Volgograd, Izd-voVolGU. 395 p. (in Russian).

Skripkin A.S., 1984. The Lower Volga region of in the first centuries $A D$. Saratov, Izd-vo Sarat. un-ta. 150 p. (in Russian).

Skripkin A.S., 1991. Anthropomorphic figurines in the burial rite of the Sarmatians. Archeology of the Eastern Europe steppe, iss. 2. Saratov, Izd-vo Sarat. un-ta, pp. 126-134. (in Russian).

Fisenko V.A., 1966. Funeral rite of the tribes of the Catacomb culture on the south-east. Arkheologicheskii sbornik. Saratov, Izd-vo Sarat. un-ta, pp. 63-83. (in Russian).

Formozov A.A., 1953. Vessels of the Srubna culture with mysterious signs. Journal of Ancient History, no. 1, pp. 1-8. (in Russian).

Khabarova N.V., 1993. Incidental findings of the Bronze Age from the funds of the Volgograd Regional Museum of Local History. Drevnosti Volgo-Donskikh stepei: sb. nauch. st., iss. 3. Volgograd, Peremena Publ., pp. 240-247. (in Russian).

\section{Information about the Authors}

Vladislav I. Mamontov, Candidate of Sciences (History), Associate Professor, Professor of Department of National History and Local History Education, Head of Scientific and Industrial Laboratory of Archaeology and Restoration, Volgograd State Socio-Pedagogical University, Prosp. Lenina, 27, 400066 Volgograd, Russian Federation, legenda@vspu.ru.

Vasiliy V. Mataev, Candidate of Sciences (Pedagogy), Specialist-Archaeologist, Archaeological expedition Ltd., Kolkhozny Cross., 11a, 346580 Rodionovo-Nesvetayskaya Village, Rostov-on-Don, Russian Federation, legenda@vspu.ru.

\section{Информация об авторах}

Владислав Иванович Мамонтов, кандидат исторических наук, доцент, профессор кафедры отечественной истории и историко-краеведческого образования, заведующий научно-производственной лабораторией археологии и реставрации, Волгоградский государственный социально-педагогический университет, просп. им. В.И. Ленина, 27, 400066 г. Волгоград, Российская Федерация, legenda@vspu.ru.

Василий Владимирович Матаев, кандидат педагогических наук, специалист-археолог, ООО «Археологическая экспедиция», пер. Колхозный, 11a, 346580 сл. Родионово-Несветайская, Ростовская область, Российская Федерация, legenda@vspu.ru. 